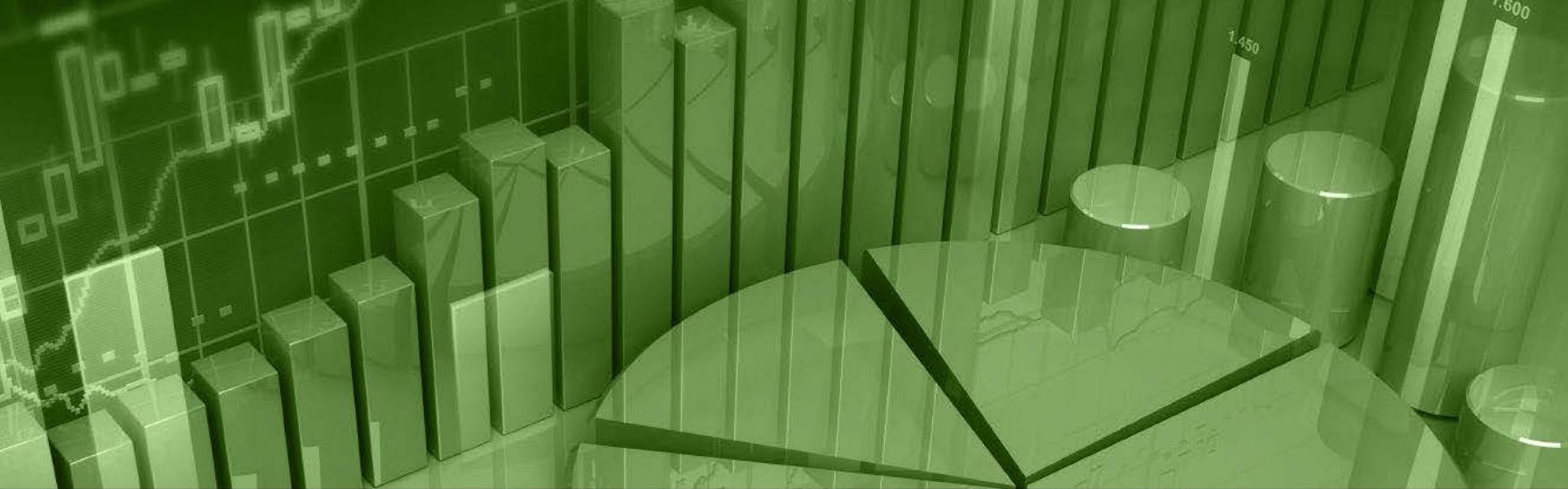

\title{
The implied cost of capital of government's claim and the present value of tax shields: A numerical example
}

By M.B.J. Schauten and B. Tans

M.B.J. Schauten is Assistant Professor in Finance, Erasmus University Rotterdam, Netherlands

This paper provides a numerical example of how to calculate the cost of capital of government's claim $\left(r_{g}\right)$ and the present value of tax shields. Schauten and Tans (2006) show for the models used in Myers (1974), Miles and Ezzell (1980) and Harris and Pringle (1985), that the present value of tax shields is equal to the difference between the present value of the expected taxes paid by the unlevered firm and the levered firm, with each of the models' implied $r_{g}$ as discount rate. We discuss a numerical example using the valuation framework by Schauten and Tans (2006) and give a logic explanation for the low implied $r_{g}$ of Miles and Ezzell's and Harris and Pringle's model.

Keywords: Corporate tax, Present value of tax shields, Required return on government's claims, Cost of capital, WACC

\section{Introduction}

This paper provides a numerical example of how to calculate the cost of capital of government's claim $\left(r_{g}\right)$ and the present value of tax shields. Schauten and Tans (2006) show for the models used in Myers (1974), Miles and Ezzell (1980) and Harris and Pringle (1985), that the present value of tax shields is equal to the difference between the present value of the expected taxes paid by the unlevered firm and the levered firm, with each of the models' implied $r_{g}$ as discount rate. We discuss a numerical example using the valuation framework by Schauten and Tans (2006) and give a logic explanation for the low implied $r_{g}$ of Miles and Ezzell's and Harris and Pringle's model.

This paper is organized as follows. Section 2 presents the valuation framework by Schauten and Tans (2006) and their derivation of a general formula for $r_{g}$ including a comparison of the implied $r_{g}$ for the models used by Myers (1974), Miles and Ezzell (1980) and Harris and Pringle (1985). ' Section 3 contains the numerical example for a hypothetical firm. Section 4 concludes.

\section{Valuation framework}

The total value of the firm (TV) is calculated on a beforetax basis and is equal to the sum of the present values of equity (E), debt (D) and government's claim (G). We assume $T V$ does not depend on leverage. ${ }^{2}$ This implies that the $T V$ of an unlevered firm is equal to the $T V$ of an (except for leverage) identical levered firm.

As shown in Table 1, TV at $t=0$ of the unlevered, as well as the levered firm, is equal to the present value of the expected $O C F$ s, where the $O C F$ at $t=1$ is equal to the earnings before interest and taxes (EBIT) minus $g Z^{3}$. We assume $O C F$ is a growing perpetuity. The discount rate for both streams of cash flows is the same since the risk of the OCF of the unlevered firm and the levered firm is equal. 


\section{Table 1: Valuation framework}

Note: This table presents the value at $t=0$ of the claims hold by the government $(G)$, equity holders (E) and debt holders (D) for an unlevered (column A) and levered (column B) firm. EBIT is the expected earnings before interest and tax at $t=1 . G$ is the present value of the expected taxes at $t=0 ; G_{u}$ for an unlevered firm, $G_{l}$ for a levered firm. $E$ and $D$ are the value at $t=0$ of equity and debt, respectively; $E_{u}$ is the value of equity at $t=0$ for an unlevered firm, $E_{1}$ is the value of equity for a levered firm at $t=0 . T V$ is the total value of the firm at $t=0$ and equals $(G+E+D)$. $\tau$ is the corporate tax rate, $g$ is the expected growth rate, $g Z$ is the net investment in fixed assets and working capital at $t=1, r_{u}$ is the cost of capital of an unlevered firm and the total firm $(G+E+D), r_{g}$ is the cost of capital for government's claims, $r_{e}$ and $r_{d}$ are the cost of equity and debt (for the levered firm), respectively.

1) $G$

$$
G_{u}=\frac{(E B I T) \tau}{r_{u}-g}
$$

2) $E$

$$
E_{u}=\frac{(E B I T)(1-\tau)-g Z}{r_{u}-g}
$$

3) $D$

4) TV

$$
0
$$

$$
\frac{(E B I T)-g Z}{r_{u}-g}
$$

$$
\begin{gathered}
G_{l}=\frac{\left(E B I T-r_{d} D\right) \tau}{r_{g}-g} \\
E_{l}=\frac{\left(E B I T-r_{d} D\right)(1-\tau)-g Z+g D}{r_{e}-g} \\
D=\frac{r_{d} D-g D}{r_{d}-g} \\
\frac{(E B I T)-g Z}{r_{u}-g}
\end{gathered}
$$

For the unlevered firm, $E$ at $t=0\left(E_{n}\right)$ is the present value of the expected ECFs. The ECF at $t=1$ is EBIT after tax at $t=1$ minus $g Z$. The discount rate for the ECFs is $r_{u}$ the unlevered cost of equity. $G_{u}$ is the present value at $t=0$ of the expected EBITs times the corporate tax rate $\tau$. We assume the risk of the $E C F$ for the unlevered firm is equal to the risk of the $O C F$, since the only risk for both streams is the business risk of the assets. This implies the same cost of capital for the claim of the government as well. $T V$ of the unlevered firm at $t=0$ is $G_{u}$ plus $E_{u}$. (If we add A1 and A2 from Table 1, we find A4.)

For the levered firm, $E$ at $t=0\left(E_{1}\right)$ is the present value of the expected $E C F s$, where the $E C F$ at $t=1$ is equal to the net earnings after tax minus $g Z$ plus $g D$ ( $g$ times the amount of debt at $t=0) .{ }^{4}$ We further assume a constant leverage ratio, ${ }^{5}$ a fixed cost of debt $\left(r_{d}\right)$ and a dividend that is equal to the ECF. The discount rate for the ECFs $\left(r_{e}\right)$ is higher than $r_{u}$ because of the leverage effect. $G_{l}$ at $t=0$ is the present value of the expected earnings times $\tau$. The discount rate for the tax payments, $r_{g}$, is not equal to $r_{u}$ (as it was for the unlevered firm) nor is it equal to $r_{e}$ of the levered firm. However, since $r_{u}$ is the discount rate for $T V$, the weighted average of the discount rates of $E, D$ and $G$ must equal $r_{u}$ :

$$
r_{g} G_{l}+r_{e} E_{l}+r_{d} D=r_{u}
$$

For the levered firm, $T V$ at $t=0$ is $G_{l}$ plus $E_{l}$ plus $D$. (If we add $B 1, B 2$ and B3 from Table 1, we find $T V$ in B4.)
In the traditional way, the PVTS could be derived directly by discounting the expected tax savings due to debt financing. ${ }^{6}$ The approach we follow recognizes that the value of equity plus debt of a levered firm $\left(V_{l}\right)$ is equal to the value of an unlevered firm $\left(V_{u}\right)$ plus the PVTS:

$$
E_{l}+D=V_{u}+P V T S
$$

Since we assume that $T V$ of the unlevered firm $\left(G_{u}+E_{u}\right)$ is equal to $T V$ of the levered firm $\left(G_{l}+E_{l}+D\right)$, it follows that,

$$
\text { PVTS }=G_{u}-G_{l}
$$

Following this approach, the PVTS is defined as (see Al and B1 from Table 1):

$$
P V T S=G_{u}-G_{l}=\frac{(E B I T) \tau}{r_{u}-g}-\frac{\left(E B I T-r_{d} D\right) \tau}{r_{g}-g}
$$

Equation (5) can be rewritten as:

$$
\text { PVTS }=\frac{r_{g}-r_{u}}{r_{u}-g} G_{l}+\frac{r_{d}}{r_{u}-g} D \tau
$$

To derive the general formula for $r_{g^{\prime}}$ we make use of column B of Table 1:

$$
G_{l}=T V-E_{l}-D=\frac{E C F+D C F+G C F}{r_{u}-g}-E_{l}-D
$$


If we multiply each side by $\left(r_{u}-g\right)$ and substitute $E_{l}\left(r_{e}-g\right), D\left(r_{d}-g\right)$ and $G_{l}\left(r_{g}-g\right)$ for ECF, DCF and GCF, respectively, we find:

$G_{l}\left(r_{u}-g\right)=E_{l}\left(r_{e}-g\right)+D\left(r_{d}-g\right)+G_{l}\left(r_{g}-g\right)-E_{l}\left(r_{u}-g\right)-D\left(r_{u}-g\right)$

Equation (8) can be rewritten as:

$r_{g}=r_{u}+\frac{D}{G_{l}}\left(r_{u}-r_{d}\right)-\frac{E}{G_{l}}\left(r_{e}-r_{u}\right)$

Equation (9) is the general formula for $r_{g} \cdot{ }^{7}$ If debt is zero, then $r_{g}=r_{e}=r_{u}$. If debt is higher than 0 , we expect $r_{g}$ to be higher than $r_{u}$. However, as will be shown in the next section, this is not always true.

To derive the implied $r_{g}$ for the models used by Myers (1974), Miles and Ezzell (1980) and Harris and Pringle (1985) we insert the equity functions as summarized in Table 2 into $(9)^{8}$. The implied $r s$ for the models are given in Table 3 . If we insert the implied $r s$ from Table 3 into (6) we find for each of the models the PVTS as presented in Table 2.

\section{Table 2: APV, WACC and $r_{\mathrm{e}}$}

Note: This table presents the adjusted present value (APV), weighted average cost of capital (WACC) and the cost of equity formulas for the models used by Myers (1974), Miles and Ezzell (1980) and Harris and Pringle (1985). $V_{l}$ is the value of a levered firm, $V_{u}$ is the value of an unlevered firm, PVTS is the present value of the tax shield, $\tau$ is the corporate tax rate, $D$ is the value of debt, $E$ is the value of equity, $L=D / V, r_{d}$ is the cost of debt, $r_{u}$ is the cost of capital of an unlevered firm, $r_{a}$ is the 'textbook' weighted average cost of capital (WACC), and $r_{e}$ is cost of equity.

\begin{tabular}{|c|c|c|c|}
\hline Model & $\begin{array}{c}\text { Adjusted Present Value } \\
V_{u} \text { plus PVTS }\end{array}$ & $\begin{array}{l}\text { Weighted Average } \\
\text { Cost of Capital }\end{array}$ & Cost of Equity \\
\hline Myers (1974) & $V l=V_{u}+\frac{r_{d} \tau D}{r_{d}-g}$ & $r_{a}=r_{u}-\left(\frac{r_{u}-g}{r_{d}-g}\right) r_{d} \tau L$ & $r_{e}=r_{u}+\left(r_{u}-r_{d}\right)\left(1-\frac{r_{d} \tau}{r_{d}-g}\right)\left(\frac{D}{E}\right)$ \\
\hline Miles and Ezzell (1980) & $V_{l}=V_{u}+\left(\frac{1+r_{u}}{1+r_{d}}\right)\left(\frac{r_{d}}{r_{u}-g}\right) \tau D$ & $r_{a}=r_{u}-\left(\frac{1+r_{u}}{1+r_{d}}\right) r_{d} \tau L$ & $r_{e}=r_{u}+\left(r_{u}-r_{d}\right)\left(1-\frac{r_{d} \tau}{1+r_{d}}\right)\left(\frac{D}{E}\right)$ \\
\hline Haris and Pringle (1985) & $V_{l}=V_{u}+\frac{r_{d} \tau D}{r_{u}-g}$ & $r_{a}=r_{u}-r_{d} \tau L$ & $r_{e}=r_{u}+\left(r_{u}-r_{d}\right)\left(\frac{D}{E}\right)$ \\
\hline
\end{tabular}

If we compare the formulas in Table 3, we find that the implied $r_{g}$ for Harris and Pringle's model is not and for Miles and Ezzell's model is almost not influenced by leverage. For both models (in contrast to that of Myers), it seems that the risk of the claim of the government is (and for Miles and Ezzell, almost) independent of leverage. At first, this finding may seem hard to explain. As we know, $r$ increases with leverage, because of the increase in financial risk. That is, equity holders hold a residual claim just like the government. Firms first pay interest, then tax and dividends. If leverage increases the variability in ECFs, it increases the variability in GCFs as well. However, under the assumptions we made, the low $r_{g}$ for Harris and Pringle's model and Miles and Ezzell's are a logic consequence which will be illustrated in the next section with a numerical example.
Note: This table presents the cost of government's claim, $r_{g^{\prime}}$ for the models used by Myers (1974), Miles and Ezzell (1980) and Harris and Pringle (1985). We derived $r_{g}$ by inserting the cost of equity functions from Table 2 into equation (9). $r_{u}$ is the cost of capital of an unlevered firm, $r_{d}$ is the cost of debt, $D$ is the market value of debt, $G_{l}$ is the present value of the expected taxes levered firm, $\tau$ is the corporate tax rate and $g$ the expected growth rate.

Table 3: Implied $r_{g}$ Model Government Risk Rate

Myers (1974)

$$
r_{g}=r_{u}+\frac{D}{G_{l}}\left(r_{u}-r_{d}\right) \frac{r_{d} \tau}{r_{d}-g}
$$

Miles and Ezzell (1980)

$$
r_{g}=r_{u}+\frac{D}{G_{l}}\left(r_{u}-r_{d}\right) \frac{r_{d} \tau}{1+r_{d}}
$$

Haris and Pringle (1985)

$$
r_{g}=r_{u}
$$




\section{A numerical example: rg and the PVTS for three classical models}

In this section, we provide a numerical example of how to calculate $r_{g}$ for the models of Myers, Harris and Pringle and Miles and Ezzell. We show that PVTS is equal to the present value of the expected tax shields and equal to $G_{u}$ minus $G_{1}$. Further, we give a logical explanation for the low implied $r_{g} s$ for Harris and Pringle's (and Miles and Ezzell's) model. We look at two scenarios. In scenario one, we assume the expected growth rate is zero, while in scenario two, we assume an expected growth rate of $2.5 \%$.

The firm's balance sheets, profit and loss accounts, cash flows, valuation parameters and calculations for scenario one and two are presented in Table 4 and Table 5 , respectively. The balance sheets at $t=0$ and the profit and loss accounts at $t=1$ are identical for both scenarios. However, the expected cash flows at $t=1$, except for the government cash flow $(G C F)^{9}$, differ because of the investments that have to be made at $t=1$. Under the no growth scenario, the firm must invest to maintain its fixed assets at a level that enables it to ensure constant cash flows. Under this scenario, working capital remains constant. This implies that the yearly investment is equal to the depreciation of its fixed assets. Under the growth scenario, the firm has to invest more to achieve growth. This extra investment at the end of year $t$ equals $2.5 \%$ of the book value of its assets at the beginning of year $t$. The firm starts to invest in growth at $t=1$. The dividend under each scenario is equal to ECF.

The cost of capital for the government, $r_{g}$, is calculated as follows. First we calculate $V_{1}$ using the APV method with the formulas from column 2 of Table 2 . We calculate the market value of $E$ by subtracting $D$ from $V_{l}$. We then calculate $T V$ by discounting the $O C F(E C F+D C F+G C F)$ using $r_{u}$ as discount rate and $G_{l}$ by subtracting $V_{l}$ from $T V$. We calculate $r_{e}$ using the formulas from column 4 of Table 2. Finally, to find $r_{g}$ for the three models, we insert the appropriate value for $r_{u}, r_{e}, D, E$, and $G_{l}$ into (9)..$^{10}$ Tables 4 and 5 present the alternative calculation for the PVTS following equation (4), as well as an alternative calculation for $G_{l}$. PVTS is equal to the present value of the expected tax shields but is also equal to the difference between $G_{u}$ and $G_{l}$. In addition, $G_{l}$ is the difference between $T V$ and $V_{l}$, and is equal to the present value of the expected tax payments with $r_{g}$ as discount rate. Under both scenarios, the implied $r_{g}$ for Miles and Ezzell's model as well as for Harris and Pringle's model is close to or equal to $r_{u}$. This low $r_{g}$ can be explained as follows. For Miles and Ezzell's model, the weighted average of $r_{d}$ and $r_{e}$ is close to $r_{u^{\prime}}$ and for Harris and Pringle, it is equal to $r_{u}$. Since the total cost of capital of $T V$ is $r_{u^{\prime}}$, the implied $r_{g}$ is close to or equal to $r_{u}$. After all, the weighted average of $r_{d}, r_{e}$ and $r_{g}$ equals the cost of capital of TV, see (2).

The implied $r_{g}$ for Myers' model is higher than the implied $r_{g} s$ of the former models. The explanation follows the same line of arguments. Since the weighted average of $r_{d}$ and $r_{e}$ is lower than $r_{u}$ (because the discount rate for PVTS is lower than $r_{u}$ ), ${ }^{11}$ and the total cost of capital of $T V$ is still $r_{u}, r_{g}$ must be higher than $r_{u}$. The difference between $r_{g}$ in the non-growth and growth scenario for Myers' model can be explained by the difference in the relative value of $V_{u}$ and PVTS. Because the cash flows from operations and the cash flows from the tax shields are discounted at different rates, their respective values are affected differently nonproportionally by growth. Hence the weighted average of $r_{d}$ and $r_{e}$ becomes a function of growth (see Ehrhardt and Daves, 2002). If $r_{d}$ is the discount rate for the tax shield, the weighted average of $r_{d}$ and $r_{e}$ decreases with growth. Since the cost of capital of $T V$ remains $r_{u}$, and is equal to the weighted average of $r_{d}, r_{e}$ and $r_{g}, r_{g}$ increases with growth. ${ }^{12}$

\section{Summary}

The total value of a firm comprises the present value of equity cash flows, debt cash flows and government cash flows. The value of the claim the government is equal to the present value of the expected tax payments, with its own discount rate $r_{g}$. In this paper we discuss a numerical example of how to calculate the cost of capital of government's claim and the present value of tax shields. We show that for the models used in Myers (1974), Miles and Ezzell (1980) and Harris and Pringle (1985), the PVTS is equal to the difference between the present value of the expected taxes paid by the unlevered firm and the levered firm with each model's implied $r_{g}$ as discount rate. Given our valuation framework where we assume that $r_{u}$ is the discount for the pre-tax cash flow, we show in contrast to Myers' mode, low implied rgs for both Miles and Ezzell's model and Harris and Pringle's model. This result is a logic consequence of the assumption we made about the risk of the pre-tax cash flow. 


\section{Appendix:}

Table 4: Example without Growth

\begin{tabular}{|c|c|c|c|c|c|c|c|c|c|}
\hline $\begin{array}{l}\text { Balance } \\
\text { Sheet }\end{array}$ & $t=0$ & $t=1$ & $t=2$ & $P \& L$ & $t=1$ & $t=2$ & $\begin{array}{l}\text { Cash } \\
\text { Flows }\end{array}$ & $t=1$ & $t=2$ \\
\hline$N W C$ & 100.0 & 100.0 & 100.0 & EBITDA & 270.0 & 270.0 & EBITDA & 270.0 & 270.0 \\
\hline NFA & $1,000.0$ & $1,000.0$ & $1,000.0$ & Depreciation & 50.0 & 50.0 & I in NWC & 0.0 & 0.0 \\
\hline \multirow[t]{2}{*}{ Total Assets } & $1,100.0$ & $1,100.0$ & $1,100.0$ & EBIT & 220.0 & 220.0 & I in NFA & -50.0 & -50.0 \\
\hline & & & & Interest & 30.0 & 30.0 & OCF & 220.0 & 220.0 \\
\hline Debt & 600.0 & 600.0 & 600.0 & PBT & 190.0 & 190.0 & $G C F$ & 76.0 & 76.0 \\
\hline Equity (BV) & 500.0 & 500.0 & 500.0 & Tax & 76.0 & 76.0 & $\Delta$ Debt & 0.0 & 0.0 \\
\hline \multirow[t]{4}{*}{$\begin{array}{l}\text { Total } \\
\text { Liabilities }\end{array}$} & $1,100.0$ & $1,100.0$ & $1,100.0$ & PAT & 114.0 & 114.0 & $D C F$ & 30.0 & 30.0 \\
\hline & & & & & & & $E C F$ & 114.0 & 114.0 \\
\hline & & & & & & & $\mathrm{CCF}$ & 144.0 & 144.0 \\
\hline & & & & & & & $F C F$ & 132.0 & 132.0 \\
\hline
\end{tabular}

This table presents the balance sheets, profit and loss accounts ( $P \& L)$, cash flows and valuation for the scenario without growth. The balance sheets show net working capital (NWC), net fixed assets (NFA), and debt and the book value $(B V)$ of equity. The $P \& L$ shows earnings before interest, taxes and depreciation (EBITDA), depreciation, earnings before interest and taxes (EBIT), interest, profit before tax $(P B T)$, and tax and profit after tax $(P A T)$. The column Cash Flows presents the investment $(I)$ in NWC and
NFA, the operating cash flow (OCF), government cash flow $(G C F)$, the increase of debt ( $\triangle D e b t)$, the debt cash flow $(D C F)$, the equity cash flow $(E C F)$, the capital cash flow $(C C F)$ and the free cash flow $(F C F)$. The valuations items are measured at $t=0$ : the unlevered value of the firm $(V u)$, the present value of tax shields (PVTS), the value of equity of the levered firm $\left(E_{l}\right)$, the value of the government's claim for a levered firm $\left(G_{l}\right)$ and an unlevered firm $\left(G_{u}\right)$ and Total Value $(T V)$. 


\section{Table 4 (Continued)}

Valuation Parameters

$g=$ growth rate $=0 \% ; r_{d}=$ cost of debt $=5 \%$;

$r u=$ cost of unlevered firm $=10 \% ; \tau=$ corporate tax rate $=40 \%$

Application APV to find $V$

$V_{l}=E+D=V_{u}+P V T S$

$V_{u}=F C F_{1} /\left(r_{u}\right)=132 /(0.1)=1,320$

PVTS Myers $(1974)=(0.05 \times 0.4 \times 600) / 0.05=240$

$V_{l}=1,320+240=1,560 \cdot E=1,560-600=960$

PVTS Miles and Ezzell $(1980)=((1+0.1) /(1+0.05)) \times(0.05 / 0.1) 0.4 \times 600=125.71$

$V_{l}=1,320+125.71=1,445.71 . E=1,445.71-600=845.71$

PVTS Harris and Pringle $(1985)=(0.05 \times 0.4 \times 600) / 0.1=120$

$V_{l}=1,320+120=1,440 . \mathrm{E}=1,440-600=840$

Present value of government's claim $\left(G_{l}\right)$

$G_{l}=T V-V_{l}$

$T V=E+D+G=(E C F+D C F+G C F) / r_{u}=(101.5+15+76) / 0.1=2,200$

$G_{l}$ Myers $(1974)=2,200-1,560=640$

$G_{l}$ Miles and Ezzell $(1980)=2,200-1,445.71=754.29$

$G_{l}$ Harris and Pringle $(1985)=2,200-1,440=760$

Required return on equity $\left(r_{c}\right)$

$\left.r_{e} \operatorname{Myers}(1974)=0.1+(0.1-0.05) \times(1-(0.05 \times 0.4) / 0.05)\right) \times(600 / 960)=11.88 \%$

$r_{e}$ Miles and Ezzell $(1980)=0.1+(0.1-0.05) \times(1-(0.05 \times 0.4) /(1+0.05)) \times(600 / 845.71)=13.48 \%$

$r_{e}$ Harris and Pringle $(1985)=0.1+(0.1-0.05) \times(600 / 840)=13.57 \%$

Cost of government's claim $\left(r_{g}\right)$

$r_{g}$ Myers $(1974)=0.1+(600 / 640) \times(0.1-0.05)-(960 / 640) \times(0.1188-0.1)=11.88 \%$

$r_{g}$ Miles and Ezzell $(1980)=0.1+(600 / 754.29) \times(0.1-0.05)-(845.71 / 754.29) \times(0.1348-0.1)=10.08 \%$

$r_{g}$ Harris and Pringle $(1985)=0.1+(600 / 760) \times(0.1-0.05)-(840 / 760) \times(0.1357-0.1)=10 \%$

Alternative valuation method for PVTS

PVTS $=G_{u}-G_{l}$

$G_{u}=T V-V_{u}=2,200-1,320=880$

PVTS Myers (1974) $=G_{u}-G_{l}$ Myers $(1974)=880-640=240$

PVTS Miles and Ezzell $(1980)=G_{u}-G_{l}$ Miles and Ezzell $(1980)=880-754.29=125.71$

PVTS Harris and Pringle $(1985)=G_{u}-G_{l}$ Harris and Pringle $(1985)=880-760=120$

Alternative valuation method for present value of government's claim $\left(G_{l}\right)$

$G_{l}=G C F_{1} / r_{g}$

$G_{l}$ Myers $(1974)=76 / 0.1188=640$

$G_{l}$ Miles and Ezzell $(1980)=76 / 0.1008=754.29$

$G_{l}$ Harris and Pringle $(1985)=76 / 0.10=760$ 


\section{Table 5: Example with Growth}

\begin{tabular}{|c|c|c|c|c|c|c|c|c|c|}
\hline $\begin{array}{l}\text { Balance } \\
\text { Sheet }\end{array}$ & $t=0$ & $t=1$ & $t=2$ & $P \& L$ & $t=1$ & $t=2$ & $\begin{array}{l}\text { Cash } \\
\text { Flows }\end{array}$ & $t=1$ & $t=2$ \\
\hline$N W C$ & 100.0 & 102.5 & 105.1 & EBITDA & 270.0 & 276.8 & EBITDA & 270.0 & 276.8 \\
\hline NFA & $1,000.0$ & $1,025.0$ & 1050.6 & Depreciation & 50.0 & 51.3 & I in NWC & -2.5 & -2.6 \\
\hline \multirow[t]{2}{*}{ Total Assets } & $1,100.0$ & $1,127.5$ & $1,155.7$ & EBIT & 220.0 & 225.5 & I in NFA & -75.0 & -76.9 \\
\hline & & & & Interest & 30.0 & 30.8 & OCF & 192.5 & 197.3 \\
\hline Debt & 600.0 & 615.0 & 630.4 & PBT & 190.0 & 194.8 & GCF & 76.0 & 77.9 \\
\hline Equity (BV) & 500.0 & 512.5 & 525.3 & Tax & 76.0 & 77.9 & $\Delta$ Debt & 15.0 & 15.4 \\
\hline \multirow[t]{4}{*}{$\begin{array}{l}\text { Total } \\
\text { Liabilities }\end{array}$} & $1,100.0$ & $1,127.5$ & $1,155.7$ & PAT & 114.0 & 116.9 & $D C F$ & 15.0 & 15.4 \\
\hline & & & & & & & $E C F$ & 101.5 & 104.0 \\
\hline & & & & & & & $\mathrm{CCF}$ & 116.5 & 119.4 \\
\hline & & & & & & & $F C F$ & 104.5 & 107.1 \\
\hline
\end{tabular}

This table presents the balance sheets, profit and loss accounts (P \& L), cash flows and valuations for the scenario with growth. The balance sheets show net working capital $(N W C)$, net fixed assets (NFA), and debt and the book value $(B V)$ of equity. The $\mathrm{P} \& \mathrm{~L}$ shows earnings before interest, taxes and depreciation (EBITDA), depreciation, interest, profit before tax $(P B T)$, and tax and profit after tax (PAT). The column Cash Flows presents the investment $(I)$ in NWC and NFA, the operating cash flow $(O C F)$, government cash flow $(G C F)$, the increase of debt $(\triangle D e b t)$, the debt cash flow $(D C F)$, the equity cash flow $(E C F)$, the capital cash flow (CCF) and the free cash flow (FCF). The valuations items are measured at $t=0$ : the unlevered value of the firm $\left(V_{u}\right)$, the present value of tax shields $(P V T S)$, the value of equity of the levered firm $\left(E_{l}\right)$, the value of the government's claim for a levered firm $\left(G_{l}\right)$ and an unlevered firm $\left(G_{u}\right)$ and Total Value $(T V)$.

Valuation Parameters

$g=$ growth rate $=2.5 \% ; r_{d}=$ cost of debt $=5 \%$;

$r_{u}=$ cost of unlevered firm $=10 \% ; \tau=$ corporate tax rate $=40 \%$

Application APV to find $V_{1}$

$V_{l}=E+D=V_{u}+P V T S$

$V_{u}=F C F_{1} /\left(r_{u}-g\right)=104.5 /(0.1-0.025)=1,393.33$

PVTS Myers $(1974)=(0.05 \times 0.4 \times 600) /(0.05-0.025)=480$

$V_{1}=1,393 \cdot 33+480=1,873 \cdot 33 . E=1,873 \cdot 33-600=1,273 \cdot 33$

PVTS Miles and Ezzell $(1980)=((1+0.1) /(1+0.05)) \times(0.05 /(0.1-0.025)) 0.4 \times 600=167.62$

$V_{l}=1,393.33+167.62=1,560.95 . E=1,560.95-600=960.95$

PVTS Harris and Pringle $(1985)=(0.05 \times 0.4 \times 600) /(0.1-0.025)=160$

$V_{1}=1,393.33+160=1,553 \cdot 33 . E=1,553 \cdot 33-600=953.33$

Present value of government's claim $\left(G_{i}\right)$

$$
\begin{aligned}
& G_{l}=T V-V_{l} \\
& T V=E+D+G=(E C F+D C F+G C F) /\left(r_{u}-g\right)=(114+30+76) /(0.1-0.025)=2,566.67 \\
& G_{l} \text { Myers }(1974)=2,566.67-1,873.33=693.33 \\
& G_{l} \text { Miles and Ezzell }(1980)=2,566.67-1,560.95=1,005.71 \\
& G_{l} \text { Harris and Pringle }(1985)=2,566.67-1,553.33=1,013.33
\end{aligned}
$$


Required return on equity $\left(r_{c}\right)$

$r_{e}$ Myers $(1974)=0.1+(0.1-0.05) \times(1-(0.05 \times 0.4) /(0.05-0.025)) \times(600 / 1,273.33)=10.47 \%$

$r_{e}$ Miles and Ezzell $(1980)=0.1+(0.1-0.05) \times(1-(0.05 \times 0.4) /(1+0.05)) \times(600 / 960.95)=13.06 \%$

$r_{e}$ Harris and Pringle $(1985)=0.1+(0.1-0.05) \times(600 / 953.33)=13.15 \%$

Cost of government's claim $\left(r_{g}\right)$

$r_{g}$ Myers $(1974)=0.1+(600 / 693.33) \times(0.1-0.05)-(1,273.33 / 693.33) \times(0.1047-0.1)=13.46 \%$

$r_{g}$ Miles and Ezzell $(1980)=0.1+(600 / 1,005.71) \times(0.1-0.05)-(960.95 / 1,005.71) \times(0.1306-0.1)=10.06 \%$

$r_{g}$ Harris and Pringle $(1985)=0.1+(600 / 1,013.33) \times(0.1-0.05)-(953.33 / 1,013.33) \times(0.1315-0.1)=10.00 \%$

Alternative valuation method for PVTS

$P V T S=G_{u}-G_{l}$

$G_{u}=T V-V_{u}=2,566.67-1,393.33=1,173.33$

PVTS Myers $(1974)=G_{u}-G_{l}$ Myers $(1974)=1,173.33-693.33=480$

PVTS Miles and Ezzell $(1980)=G_{u}-G_{l}=1,173.33-1,005.71=167.62$

PVTS Harris and Pringle $(1985)=G_{u}-G_{l}=1,173.33-1,013.33=160$

Alternative valuation method for present value of government's claim $\left(G_{1}\right)$

$\left.G_{l}=G C F_{1} / r_{g}-g\right)$

$G_{l}$ Myers $(1974)=76 /(0.1346-0.025)=693.33$

$G_{l}$ Miles and Ezzell $(1980)=76 /(0.1006-0.025)=1,005.71$

$G_{l}$ Harris and Pringle $(1985)=76 /(0.10-0.025)=1,013.33$

\section{References}

Brealey, R.A., Myers, S.C. and Allen, F. (2014), Principles of corporate finance. McGraw-Hill, New York.

Ehrhart, M.C. and Daves, P.R. (2002), Corporate valuation: the combined impact of growth and the tax shield of debt on the cost of capital and systematic risk. Journal of Applied Finance, Fall/Winter, 31-38.

Harris, R.S. and Pringle, J.J. (1985), Risk-adjusted discount rates - extensions from the average-risk case. The Journal of Financial Research 8 (3), 237-244.

Myers, S.C., (1974), Interactions of corporate financing and investment decisions-implications for capital budgeting. Journal of Finance 29, 1-25.
Miles, J. and Ezzell, J. (1980), The weighted average cost of capital, perfect capital markets and project life: a clarification. Journal of Financial and Quantitative Analysis 48, 719-730.

Modigliani, F. and Miller, M.H. (1958), The cost of capital, corporation finance and the theory of investment. American Economic Review 48, 261-297.

Ruback, R.S., (2002), Capital cash flows: a simple approach to valuing risky cash flows. Financial Management, Summer, 85-103.

Schauten, M.B.J. and Tans, B. (2006), Cost of capital of government's claims and the present value of tax shields. Financieel Forum / Bank- en financiewezen 2006/2, 86-89. 


\section{Notes:}

1. Ruback (2002) makes the same assumption about the risk of the PVTS as Harris and Pringle (1985) do, and use the same implied implied $r_{g}$ as a result.

2. This is in accordance with Proposition I of Modigliani and Miller (1958), see Brealey et al. (2014), p. 450. We ignore costs / benefits related to leverage.

3. $g Z$ is the net investment at $t=1$ in fixed assets and working capital to achieve growth $(g)$. In our model, $Z$ is the book value of the net fixed assets and working capital at $t=0$.

4. A net increase of debt at $t=1$ is an outflow for the debt holders, but an inflow for the equity holders.

5. The leverage ratio is expected to be constant in market values as well as book values over time, although both ratios could differ.

6. Note that the value of the firm in this traditional sense is only $E$ plus $D$ since it ignores the present value of the expected taxes for the government.

7. Equation (9) is the general formula for $r_{g}$ under the assumption that $r_{u}$ is the discount rate for the pre-tax cash flows. If we do not make this restriction we find; $r_{g}=r_{t v}+\left(D / G_{l}\right)(r t v-r d)-\left(E / G_{l}\right)\left(r_{e}-r_{t v}\right)$ where $r_{t v}$ is the pre-tax discount rate. For the unlevered firm, the implied cost of capital of government's claim $\left(r_{g u}\right)$ then is; $r_{t v}-\left(E_{u} / G_{u}\right)\left(r_{u}-r_{t v}\right)$, and the PVTS $=(E B I T) \tau /\left(r_{g u}-g\right)-\left(\left(E B I T-r_{d} D\right) \tau\right) /\left(r_{g}-g\right)$.

8. See Ehrhart and Daves (2002) for general formulas.

9. The GCFs are identical because GCF is a percentage of earnings before tax at $t=1$.

10. An alternative for this last step is to use the derived relations from Table 3.

11. The weighted average of the required returns of the assets in the traditional sense, i.e., $V_{u}+$ PVTS, equals the weighted average of the required returns of the providers of capital $(E+D)$.

12. In the model used by Myers, re decreases from $11.88 \%$ to $10.47 \%$ because i) the risk of the assets $\left(V_{u}+P V T S\right)$ decreased as a result of an increase in the PVTS as percentage of $V_{l}$, and ii) leverage (D/E) decreased. Leverage decreased due to growth because debt at $t=0$ is fixed and the value of this firm is positively related to growth (i.e., the return on new invested capital is higher than the cost of capital).

\section{Corresponding Author:}

M.B.J. Schauten, Erasmus University Rotterdam, Postbus 1738, 3000 DR, Rotterdam, Netherlands. Email schauten@ese.eur.nl 